\title{
TRADISI BAAYUN MULUD DI BANJARMASIN
}

\author{
Maimanah, M.Ag* dan Norhidayat, MA**
}

\begin{abstract}
Tulisan ini mendeskripsikan tentang tradisi baayun mulud yaitu salah satu tradisi lokal yang bernuansa religius di kalangan masyarakat Banjar. Dengan melakukan pengamatan langsung di dua tempat serta wawancara langsung terbadap pibak-pibak yang terlibat dalam pelaksanaan kegiatan ini, yaitu: di Makam Sultan Suriansyah Kecamatan Banjarmasin Utara Kota Banjarmasin dan Mesjid Jami' Teluk Dalam Kecamatan Banjarmasin Tengah Kota Banjarmasin, maka dapat ditegaskan bahwa meskipun terlibat jelas adanya unsur-unsur budaya pra-Islam dalam pelaksanaan tradisi baayun mulud ini, namun dari sisi yang lain justru menunjukkan karakter khas dari sebuah proses islamisasi di tengah-tengah masyarakat Banjar, di mana kedatangan Islam tidaklah membabat habis selurub tradisi lokal yang pernah ada di tengah-tengah masyarakat, melainkan menjadi ruh bagi tradisi yang dipandang masih layak dipertahankan dan banyak mengandung nilainilai positif
\end{abstract}

Kata kunci: Bayun Mulud, Banjarmasin, Tradisi

\section{Pendahuluan}

Bagi umat Islam di Indonesia, bulan Rabi'ul Awwal merupakan bulan yang penuh dengan keramaian. Pada bulan ini berpadu tiga peringatan peristiwa penting sekaligus, yaitu peringatan hari kelahiran Nabi Muhammad saw, hari wafatnya dan sekaligus bulan hijrahnya Nabi saw., ke Medinah. Bersandar kepada salah satu dari ketiga peristiwa besar inilah, kaum muslimin selanjutnya menamakan bulan Rabi'ul Awwal ini dengan sebutan bulan maulid (bulan kelahiran), yaitu maulid (kelahiran) Nabi Muhammad saw., yang diutus sebagai pembawa ajaran keselamatan bagi seluruh umat manusia.

Maulid Nabi Muhammad saw. di Indonesia, tampaknya telah benarbenar menjadi sebuah budaya relegius yang mapan. Ia tidak saja digelar di kalangan masyarakat awam, tetapi bahkan di kalangan istana negara oleh Presiden Republik Indonesia bersama jajaran pemerintahan sebagai agenda 
resmi kenegaraan. Selain digelar dalam beragam stratifikasi sosial, peringatan maulid di Indonesia juga dieskpresikan dalam beragam model dan tata cara yang berbeda-beda. Majalah GONG (Media Seni dan Pendidikan) edisi 69 tahun 2005 menyebutkan ada lebih dari sepuluh model ekspresi perayaan bulan maulid ini. ${ }^{1}$

Di Banjarmasin, Kalimantan Selatan, perayaan maulid diperingati dengan serangkaian acara-acara, yang biasanya terdiri dari pembacaan sya'ir-sya'ir maulid, seperti: al-Barzanji, al-Diba'i, Asyaraf al-Anam, atau maulid al-Habsyi. Dilanjutkan dengan ceramah agama. Peringatan maulid ini dilakukan di berbagai tempat, seperti: tempat-tempat ibadah; mesjid dan langgar (mushalla), sekolah-sekolah dan perkantoran, rumah-rumah penduduk, tempat-tempat keramat dan lain sebagainya. Masyarakat rela bergotong-royong untuk mempersiapkan segala sesuatu demi suksesnya perayaan ini. Biaya penyelenggaraannya pun mereka tanggung bersama-sama.

Sementara itu, sebagian masyarakat Banjar, khususnya keturunan kerajaan, ada pula yang memperingati hari kelahiran Nabi Muhammad saw. ini dengan menggelar suatu tradisi unik yang mereka sebut dengan istilah maayun anak. Karena tradisi maayun anak ini digelar seiring dengan peringatan hari kelahiran Nabi yaitu pada bulan maulid, maka upacara ini dalam bahasa Banjar dinamakan dengan istilah baayun mulud.

Pada perkembangan beberapa tahun terakhir ini, upacara baayn mulud semakin banyak diminati masyarakat, terbukti dengan semakin bertambahnya peserta yang hadir meramaikan, dan yang ikut maayun anak tidak lagi terbatas untuk keturunan kerajaan saja, tetapi juga orang yang bukan keturunan

\footnotetext{
*Dosen Mata Kuliah Sosiologi Agama Fakultas Ushuluddin IAIN Antasari Banjarmasin

**Dosen Mata Kuliah Metodologi Studi Islam Fakultas Ushuluddin IAIN Antasari Banjarmasin

${ }^{1}$ Di Jawa Tengah dikenal dengan istilah grebeg maulud atau sekaten, di Pemalang (Jawa Tengah) pada tanggal 12 Rabi'ul Awwal masyarakat menggelar tablil, jamasan dan tirakah di makam Syekh Pandanjati, masyarkat Sunda mengisi perayaan maulid dengan membacakan wawacan yaitu seni baca naskah berbentuk langgam pupuk yang berisi tentang kisah-kisah nabi dengan bahasa Sunda dan bertuliskan huruf arab, di Maluku Utara tepatnya di daerah Jati, masyarakat Gamkonora menyajikan dabus dalam perayaan maulid. Di Padang Pariaman perayaan maulid berlangsung selama satu setengah bulan karena dilaksanakan dengan bergiliran kampung, acara diisi dengan pembacaan drikir maulid. Di Madura perayaan maulid adalah perayaan besar yang diisi dengan hadrah dan qasidab sambil berarak-arakan yang terkadang diisi dengan topeng-topengan raksasa dan macan. GONG (Media Seni dan Pendidikan Seni) Yogyakarta, edisi 69/VII/2005, h. 8-11.
} 
kerajaan. Yang lebih unik lagi, terkait dengan peserta yang diayun, bukan lagi hanya anak-anak tetapi juga orang dewasa, bahkan yang sudah tua (neneknenek). Mereka masing-masing mengikuti kegiatan ini dengan beragam kepercayaan dan motivasi tersendiri.

Tulisan ini akan mendeskripsikan tentang upacara baayun mulud yang dilaksanakan di Banjarmasin, yaitu di Kecamatan Banjarmasin Utara dan Kecamatan Banjarmasin Tengah, yang dilaksanakan pada bulan Rabi'ul Awwal tahun $1432 \mathrm{H}$, bertepatan dengan bulan Februari tahun 2011 M.

\section{Sejarah Baayun Mulud}

Sebagai sebuah tradisi lama yang dilaksanakan secara turun-temurun, jelas tidak mudah untuk menentukan kapan pertama kali kegiatan baayun mulud dilakukan dan siapa yang pertama kali memperkenalkannya di tengah-tengah masyarakat Banjar. Asal mula munculnya tradisi baayun mulud ini diduga kuat pada awalnya berkaitan erat dengan tradisi lainnya dalam masyarakat Banjar, yaitu tradisi bapalas bidan.

Tradisi bapalas bidan sendiri adalah sebuah upacara pemberkatan yang dilakukan oleh seorang bidan kampung/tradisional kepada sang jabang bayi dan ibunya. Mereka yang melaksanakan tradisi ini berpandangan bahwa jika sebuah keluarga yang baru saja menerima kehadiran seorang bayi tidak melaksanakan upacara bapalas bidan, maka seakan-akan bayi yang baru lahir tersebut dianggap sebagai anak dari bidan yang menolong prosesi persalinannya. Begitu kuatnya sebagian masyarakat Banjar mempercayai anggapan ini, sampai-sampai mereka tetap mengadakan acara bapalas bidan, meskipun yang membantu prosesi melahirkannya bukan lagi bidan tradisional atau bidan kampung, melainkan bidan yang berpendidikan modern atau dokter di rumah sakit. Mereka juga percaya, bahwa jika acara bapalas bidan ini tidak dilakukan, maka konon bayinya akan sering sakit-sakitan karena diganggu makhluk gaib.

Dalam pelaksanaan upacara bapalas bidan, disediakan ayunan (buaian) yang terdiri tiga lapis kain panjang, lapis yang paling atas biasanya berwarna kuning. Juga disediakan berbagai kue-kue dan piduduk (sesajian), baik piduduk kering maupun piduduk basah, dan berbagai perlengkapan lainnya. Pada prosesinya, bayi yang baru dilahirkan pertama-tama diayun atau dibuai oleh sang bidan, kemudian diserahkan kepada ibunya atau keluarganya. Selanjutnya, dibacakan do'a keselamatan dan keberkahan untuk sang bayi, juga ibu dan keluarga besarnya. Terakhir, kue-kue dan sesajian lainnya dinikmati bersama-sama. 
Tampaknya, acara bapalas bidan ini pada awalnya, lebih dimaksudkan sebagai ucapan terima kasih dari pihak keluarga yang baru saja menerima kelahiran seorang bayi kepada sang bidan yang telah membantu prosesi kelahirannya. Jika bidan zaman sekarang pada umumnya mendapat imbalan upah berupa bayaran sejumlah uang, maka dalam tradisi masyarakat Banjar tempoe dulu, tampaknya seserahan dan piduduk (sesajian) yang disediakan pihak keluarga dalam upacara bapalas bidan inilah yang menjadi tanda terima kasih pihak keluarga terhadap bidan yang telah membantu prosesi persalinan.

Pada perkembangan berikutnya, acara bapalas bidan dilakukan bersamaan waktunya dengan acara peringatan hari kelahiran Nabi Muhammad saw pada bulan maulid atau Rabi'ul Awwal. Dari sinilah kemudian muncul istilah baayun mulud. Karena sebagaimana telah dikemukakan, bahwa salah satu prosesi dalam acara bapalas bidan, adalah membuai atau mengayun bayi yang baru saja dilahirkan di dalam buaian atau ayunan. Seiring dengan perkembangan zaman, sejumlah peralatan dan sesajian pada acara bapalas bidan tetap dipertahankan dalam pelaksanaan upacara baayun mulud hingga sekarang.

Meskipun tradisi baayun mulud ini sempat dilupakan oleh sebagian masyarakat di lingkungan kota Banjarmasin, tetapi sekitar tujuh tahun terakhir ini kembali dihidupkan lagi terutama di lingkungan keluarga kerajaan Banjar. ${ }^{2}$ Tradisi ini, memang lebih banyak dilakukan oleh masyarakat Banjar, khususnya di lingkungan masyarakat Banjar Kuala, yaitu orang Banjar yang tinggal di wilayah Banjarmasin, Marabahan, Martapura, hingga Rantau. Sedangkan masyarakat Banjar Pahuluan, yaitu orang Banjar yang umumnya tinggal di wilayah hulu sungai jarang melakukan tradisi serupa.

Berikut ini dideskripsikan upacara baayun mulud yang diselenggarakan di dua wilayah dalam kota Banjarmasin:

\footnotetext{
${ }^{2}$ Wawancara dengan H. Burhan : Pengurus makam pangeran Suriansyah, pada tanggal 5 Juni 2011. Menurut H. Ahmad Yamani, ketua panitia penyelenggara, kegiatan baayun mulud ini diadakan kembali dalam rangka "menimbulakan batang nang tinggalam" maksudnya: sebagai upaya untuk menghidupkan kembali tradisi yang pernah berkembang di tengah-tengah masyarakat Banjar sejak dahulu, yaitu sejak masih berkuasanya kerajaan Banjar. Wawancara langsung pada waktu pelaksanaan kegiatan Baayun mulud hari Selasa, 15 Februari 2011/12 Rabî al-Awwal 1432 di depan makam Sultan Suriansyah Kelurahan Kuin Utara Kecamatan Banjarmasin Utara Kota Banjarmasin Provinsi Kalimantan Selatan.
} 


\section{Baayun Mulud di Kecamatan Banjarmasin Utara}

1. Kepanitiaan

Panitia penyelenggara kegiatan, selain beranggotakan mereka yang memang sehari-hari bertugas sebagai pengurus makam Sultan Suriansyah (yang pada umumnya merupakan keturunan dari Raja Banjar), dibantu juga oleh warga masyarakat yang bertempat tinggal di sekitar makam dan bahkan juga dibantu oleh aparat Kelurahan Kuin Utara, aparat Kecamatan Banjarmasin Utara dan aparat Kepolisian Sektor Banjarmasin Utara.

Panitia secara khusus mendatangkan mereka yang bertugas melantunkan sya'ir maulid ini dari kelompok yang memang khusus pembaca sya'ir yang biasa dipanggil untuk membacakan sya'ir. Panitia mengaku kesulitan untuk mencari mereka yang mampu melakukan hal ini karena relatif mulai langka keberadaannya di Banjarmasin dan sekitarnya.

\section{Peserta}

Acara baayun mulud yang diselenggarakan di depan makam Pangeran Sultan Suriansyah ini pada mula hanya terbatas hanya untuk keluarga bububan, yakni keturunan kerajaan. Namun sekarang sudah terbuka untuk umum, yaitu siapa saja yang ingin menjadi peserta, walaupun dari luar daerah dan dari suku apa saja bila berkeinginan dan mendaftarkan diri sebagai peserta maka akan diterima. Adapun peserta untuk tahun 2011 ini berjumlah 117 orang dari berbagai latar belakang. Menurut ketua panitia penyelenggara, H. Ahmad Yamani, sebenarnya peserta yang berminat untuk mengikuti kegiatan ini jauh melebihi jumlah tersebut, namun karena keterbatasan tempat kegiatan, maka panitia terpaksa membatasi jumlah mereka yang mendaftar sebagai peserta, dan sangat banyak yang tidak bisa diterima sebagai peserta. Hal ini bisa dimaklumi, karena fasilitas ayunan (buaian) yang disediakan panitia dengan luas sekitar 1,25 meter persegi untuk masing-masing peserta, terlihat begitu sesak ketika di bawahnya digunakan oleh masing-masing peserta untuk meletakkan piduduk dan sesajian lainnya dan dikerumuni pula oleh sanak famili dan kerabatnya masing-masing.

Dilihat dari usia peserta yang diayun, mayoritas berusia balita dari bayi yang baru lahir hingga usia taman kanak-kanak. Hanya beberapa di antaranya yang berusia dewasa, persisnya 3 orang nenek-nenek, berusia sekitar 50 hingga 60 tahun.

Dilihat dari asal daerah, acara baayun mulud di tempat ini diikuti terutama oleh mereka yang bertempat tinggal di sekitar lokasi kegiatan. Selain itu 
terdapat pula beberapa peserta yang berasal dari luar wilayah kota Banjarmasin. Yaitu dari Kapuas, Anjir dan Batulicin. ${ }^{3}$

Masyarakat sekitar makam sultan suriansyah secara umum tampak jelas memberikan dukungan bagi kegiatan baayun mulud ini. Hal ini ditunjukkan baik dari antusiasme mereka sebagai peserta kegiatan maupun dukungan mereka secara bersama-sama bergotong-royong mempersiapkan segala sesuatu yang terkait dengan suksesnya acara peringatan maulid Nabi Besar Muhammad saw dan kegiatan baayun mulud seperti mendirikan tenda, membuat tiang-tiang ayunan, dan menyediakan konsumsi untuk tamu undangan dan hadirin yang menghadiri peringatan maulid Nabi.

Aparat pemerintah baik yang mewakili pemerintah provinsi Kalimantan Selatan maupun kota Banjarmasin terlihat memberikan dukungan penuh dan sangat mengapresiasi kegiatan baayun mulud ini. Kegiatan ini direncanakan akan menjadi event wisata budaya yang akan digelar setiap tahun.

3. Perlengkapan/Peralatan

Untuk peserta baayun mulud, panitia sengaja mendirikan tenda besar di atas tanah kosong di halaman depan makam Sultan Suriansyah. Ukuran tenda yang didirikan dengan tiang besi dan atap terpal tersebut tidak kurang dari $25 \mathrm{X}$ 20 meter persegi.

Sebagian perlengkapan yang digunakan untuk acara baayun mulud disediakan oleh panitia dengan menggunakan dana dari uang pendaftaran dari peserta. Sebagian lagi dibawa dan ditambahkan oleh peserta masing-masing. Yang telah disiapkan atau disediakan oleh panitia, terdiri dari:

- Tiang kayu yang kokoh untuk mengantung ayunan (buaian);

- Tali tambang sebagai tali ayunan;

- Empat lembar kain (terdiri dari 1 lembar kain sarung batik, 3 lembar kain aksesoris berwana kuning dan hijau) sebagai tempat peserta yang ikut acara baayun mulud;

- Aksesoris ayunan berupa anyaman-anyaman dari daun nipah yang dibentuk burung-burung, halilipan, ular-ularan, rantai, ketupat dan lain-lain. ${ }^{4}$

Peralatan yang harus disiapkan dan dibawa sendiri oleh peserta adalah:

- "Piduduk", yaitu berupa sesajian yang disiapkan oleh peserta, umumnya berupa beras, buah kelapa, dan gula merah, jarum, benang, uang logam, selebihnya bervariasi sesuai kepercayaan. Adapun makna simbolik yang

${ }^{3}$ Wawancara dengan H. Ahmad Yamani : Ketua Panitia penyelenggra pada 15 Juni 2011

${ }^{4}$ Wawancara dengan H. Burhan pada tanggal 12 Juni 2011 
terkandung dalam benda-benda yang disediakan oleh seorang peserta. Piduduk ini diletakan dalam satu tempat khusus yang disebut sasanggan (bokor). Terkadang benda-benda perlengkapan atau peralatan ini disebut dengan istilah piduduk kering;

- Makanan (nasi ketan, telor bebek, bubur merah, bubur putih, dll) dan kue-kue di antaranya ialah kue apam, cucur, cincin, cingkarok, dll . Benda yang berupa jenis makanan ini terkadang bisa disebut piduduk basah;

- Uang kertas yang difotokopi dengan ukuran besar dengan jumlah bervariasi yang digantung melengkapi aksesoris ayunan;

- Buah-buahan yang juga digantung sebagai aksesoris ayunan. Di antara buahbuahan itu ialah jambu, salak, jeruk, apel dan lain-lain;

- Daun-daunan. ${ }^{5}$

4. Pendanaan

Aparat pemerintah baik yang mewakili pemerintah provinsi Kalimantan Selatan maupun kota Banjarmasin terlihat memberikan dukungan penuh dan sangat mengapresiasi kegiatan Baayun Mulud ini. Kegiatan ini direncanakan menjadi event wisata budaya yang akan digelar setiap tahun.

Untuk acara Baayun Mulud, panitia menghimpun dana dari uang pendaftaran peserta Baayun Mulud. Perorang diminta menyumbang sebesar Rp. 125.000,-. Di samping dari uang pendaftaran ini, panitia juga memperoleh sumbangan dana dari Gt. Muhammad Khairul Saleh, Raja Muda Banjar dan dari Gt. Muhammad Rusdi Effendi, Pimpinan Banjarmasin Post. Keduanya merupakan keturunan Raja Banjar. Bantuan yang diberikan pimpinan Banjarmasin Post, tampaknya tidak hanya berupa dana kegiatan, tetapi juga berupa peralatan, khususnya tenda-tenda kecil yang bertuliskan "Banjarmasin Post" yang digunakan untuk tempat bernaung pengunjung. ${ }^{6}$

5. Prosesi Upacara

Ada tiga acara utama yang diselenggarakan dalam rangkaian peringatan maulid Nabi Besar Muhammad saw. Ketiga acara tersebut adalah: Pertama, pembacaan sya'ir-sya'ir maulid. Kedua, kegiatan baayun mulud. Ketiga, ceramah agama sekitar maulid Nabi Muhammad saw. Acara pertama dan kedua dilakukan secara bersamaan. Setelah selesai keduanya, kemudian disusul acara ketiga sebagai puncak kegiatan.

${ }^{5}$ Wawancara dengan Badruzzaman pada tanggal 15 Juni 2011

'Wawancara langsung pada waktu pelaksanaan kegiatan Baayun Mulud hari Selasa, 15 Februari 2011/12 Rabî al-Awwal 1432 di depan makam Sultan Suriansyah Kelurahan Kuin Utara Kecamatan Banjarmasin Utara Kota Banjarmasin Provinsi Kalimantan Selatan 
Penceramahnya adalah K.H. Ali Furqan, seorang tokoh ulama yang masih berusia muda dari kota Banjarmasin. Adapun yang hadir mendengarkan ceramah, terdiri dari berbagai lapisan masyarakat termasuk aparat pemerintah, mulai dari perwakilan pemerintah provinsi Kalimantan Selatan, Wakil Walikota Banjarmasin, aparat keamanan dari Poltabes dan Kodim, juga dari kantor urusan agama kecamatan Banjarmasin Utara.

Acara dimulai sekitar pukul 08.00 pagi waktu setempat, dengan pembacaan sya'ir-sya'ir maulid syarafal anam. ${ }^{7}$ Seiring dengan itu, semua peserta yang pada umumnya bayi dan anak-anak telah mulai dimasukkan ke dalam ayunan dan mulai diayun seakan dibuai untuk ditidurkan. Menurut panitia, waktu yang paling baik untuk mengayun bayi ini, sebenarnya tepat pada saatsaat pembacaan sya'ir asyrakal (karena adanya kepercayaan di sebagian masyarakat Banjar bahwa ketika sya'ir asyrakal itu dibacakan, ruh Rasulullah saw., hadir di tengah-tengah kumpulan orang yang membacanya).

Pada awal-awal acara, sambil mulai mengayun bayi atau anak-anak dalam ayunan, sebagian anggota keluarga menambahkan pernak-pernik aksesoris pada ayunan. Sedang sebagian lainnya, menyusun dengan rapi piduduk (sesajian) di bawah ayunan yang ditempati anggota keluarganya. Baik bayi, anak-anak maupun orang dewasa yang berada dalam ayunan terus diayun selama pembacaan sya'ir maulid hingga akhir pembacaan sya'ir 'asyraqal. Setelah pembacaan sya'ir asyraqal berakhir, semua pernak-pernik aksesoris yang digantung pada ayunan demikian pula sesajian yang dihamparkan di sekitar ayunan, menjadi sesuatu yang diperebutkan oleh anggota keluarga yang sedari awal telah berkerumun di sekitar ayunan.

Selesai acara pembacaan sya'ir-sya'ir maulid dan baayun mulud, acara dilanjutkan dengan ceramah agama sekitar maulid Nabi Muhammad saw. Acara ceramah agama ini diawali dengan pembukaan dan pembacaan ayat-ayat suci al-

${ }^{7}$ Syarafal anam" adalah sebutan orang Banjar untuk nama kumpulan sya'ir-sya'ir maulid syarf al-anâm (manusia yang mulia), yang di samping berisi pujian-pujian bagi Nabi Muhammad saw., juga berisi uraian tentang sirah al-nabawiyyah (perjalanan hidup kenabian) yang penuh dengan kemuliaan, hikmah, dan keteladanan. Ada 3 jenis sya'ir maulid yang biasanya dilantunkan masyarakat Banjar ketika memperingati maulid Nabi Muhammad saw. Ketiga jenis sya'ir maulid tersebut adalah: 1) Syarafal anam (syarf al-anâm) 2) Barzanjî, dan 3) Habsyî. Sya'ir maulid yang pertama dan kedua telah sejak lama dikenal dan populer di kalangan masyarakat Banjar, sedangkan yang terakhir mulai populer sejak awal tahun 90-an. Persisnya sejak ditradisikan oleh ulama kharismatik asal Martapura, Kalimantan Selatan, K.H. Muhammad Zaini bin Abdul Ghani (w. 2005) di dalam pengajiannya di mushalla Ar Raudhah, Sekumpul, Martapura. 
Qur'ân, kemudian sambutan panitia pelaksana sekaligus pembacaan riwayat kerajaan Banjar, disusul kemudian dengan sambutan yang disampaikan langsung oleh Wakil Walikota Banjarmasin, Bapak H. M. Irwan Anshari. Kemudian, sambutan dari Gubernur Kalimantan yang diwakili oleh kepala dinas pariwisata Provinsi Kalimantan Selatan. Setelah mendengari berbagai sambutan, acara dilanjutkan dengan mendengarkan ceramah agama yang disampaikan oleh Ustadz H. Ali Furqan.

Dengan gayanya yang kocak, Ustadz H. Ali Furqan menyampaikan ceramah yang intinya adalah bagaimana agar umat Islam mencintai Rasulullah saw dan berusaha meneladani akhlak Rasulullah yang mulia. Selesai ceramah agama, acara ditutup dengan do'a yang dipimpin kembali oleh penceramah. Kemudian panitia membagikan konsumsi berupa nasi kotak untuk seluruh hadirin. Karena begitu banyaknya jumlah anggota masyarakat yang menghadiri acara ini, jumlah 1000 nasi kotak yang dibagikan panitia masih tidak mencukupi untuk keseluruhan anggota masyarakat yang hadir dalam acara tersebut. ${ }^{8}$

6. Kendala dan Tantangan yang di Hadapi

Penyelenggaraan kegiatan baayun mulud pada tahun 2011 ini sepertinya sama sekali tidak menghadapi kendala yang berarti. Satu-satunya kendala yang diungkapkan oleh ketua panitia penyelenggara, Bapak H. Ahmad Yamani adalah sempitnya lahan yang dapat digunakan sebagai lokasi mendirikan tenda untuk acara baayun mulud. Kecilnya lahan ini tidak sebanding dengan besarnya minat anggota masyarakat untuk menjadi peserta, sehingga panitia terpaksa membatasi jumlah pendaftar yang berminat.

Adapun tantangan dalam bentuk penolakan terhadap penyelenggaraan acara baayun mulud ini tidak tampak sama sekali. Justeru sebaliknya, acara ini mendapat dukungan dari berbagai pihak dan instansi pemerintahan.

\section{Baayun Mulud di Kecamatan Banjarmasin Tengah}

Kegiatan baayun mulud sebagai rangkaian acara peringatan maulid Nabi Besar Muhammad saw. di kota Banjarmasin telah diselenggarakan di beberapa tempat. Selain di Makam Sultan Suriansyah yang berada di wilayah kecamatan Banjarmasin Utara, di beberapa buah mesjid yang ada di wilayah kota Banjarmasin juga menggelar acara serupa, bahkan di salah satu hotel berbintang. 
Adapun untuk wilayah kecamatan Banjarmasin Tengah, penyelenggaraan kegiatan yang relatif besar diadakan di Mesjid Jami' Teluk Dalam.

Diadakannya kembali kegiatan baayn mulud pada tahun ini, menurut $\mathrm{H}$. Risfani, tidak lain adalah untuk menyemarakkan peringatan maulid Nabi Besar Muhammad saw. selain juga untuk menghidupkan kembali tradisi yang telah lama berkembang di kalangan masyarakat Banjar serta dalam rangka menjalin silaturrahim.

Koordinator panitia pelaksana, Bpk H. Risfani, yang juga pengurus mesjid Jami' Teluk Dalam. Dia adalah keturunan pemilik tanah waqaf untuk lokasi mesjid Jami' ini, yang berasal dari daerah Kabupaten Tapin (Rantau). Dia sangat berpengalaman menjadi panitia kegiatan baayun mulud di daerah Banua Halat.'

Baayun mulud di mesjid Jami' Teluk Dalam sudah pernah dilaksanakan pada tahun 2003 M pada saat dikelola oleh Abdul Hadi (anggota DPR). Selama tiga tahun berturut-turut, kemudian terhenti selama lima tahun, dari tahun 2005 sampai dengan tahun 2010 hal ini disebabkan panitia mesjid saat itu tidak merespon terhadap acara baayun mulud ini. Kemudian kepanitiaan mesjid berganti sejak 01 Januari 2011 yang diketuai oleh guru Imberan, dan kini dihidupkan kembali tradisi ini yang telah diprakarsai oleh Bapak H. Risfani, sehingga pada tanggal 17 Rabiul Awal $1432 \mathrm{H}$. atau tanggal 20 Pebruari 2011 M. digelar kembali acara baayun mulud ini. Bapak H. Risfani mengaku dia keturunan orang Rantau yang selalu melaksanakan baayun mulud sejak dulu dari datuk neneknya. Lebih jauh diungkapkannya, sebenarnya acara ini direncanakan pada tanggal 12 Rabiul Awal tahun 1432 H. Namun berhubung penceramah yang direncanakan berhalangan yakni bersamaan jadwalnya dengan ceramah pada acara baayun mulud di Rantau, sehingga untuk di mesjid Jami' diadakan penundaan. ${ }^{10}$

\section{Kepanitiaan}

Menurut koordinator panitia pelaksana, Bpk H. Rifani, diakui memang bahwa panitia kegiatan baayun mulud di Mesjid Teluk Dalam untuk tahun 2011 ini tampak kurang mantap melakukan persiapan. Sebab kegiatan ini hanya disiapkan dalam waktu 20 hari saja, padahal seharusnya persiapan selama 40

${ }^{9}$ Acara ini dilaksanakan di Mesjid Jami' Teluk Dalam Banjarmasin pada hari Minggu tanggal 17 Rabî' al-Awwal 1432/20 Februari 2011

${ }^{10}$ Wawancara dengan Risfani pada Tanggal 12 Juni 2011 
hari sebelum acara dilaksanakan, dan panitia tidak menduga akan besarnya antusias warga untuk mengikuti kegiatan ini.

Yang bertugas sebagai panitia penyelenggara kegiatan baayun mulud pada umumnya sekaligus merupakan pengurus mesjid Jami' Teluk Dalam. Bapak H. Risfani yang bertindak sebagai koordinator panitia pelaksana, merupakan anggota pengurus Mesjid Jami' Teluk Dalam periode sekarang ini. Beliau mengaku merupakan keturunan pemilik tanah waqaf untuk lokasi mesjid Jami' ini didirikan. Menurut beliau, selama bertugas di Dinas Pariwisata Kabupaten Tapin, beliau selalu terlibat langsung dalam kepanitiaan pada acara baayun mulud di daerah Banua Halat Kabupaten Tapin Provinsi Kalimantan Selatan. Sebagaimana dimaklumi bahwa acara baayun mulud di daerah ini telah sejak lama diadakan dan setiap tahunnya selalu diikuti oleh ratusan bahkan pada tahun 2011 ini mencapai seribu lebih peserta.

Dalam rangka persiapan penyelenggaraan kegiatan baayun mulud di mesjid Jami' Teluk Dalam pada tahun 2011 ini, panitia telah memasang beberapa spanduk pengumuman pemberitahuan kegiatan di beberapa sudut kota Banjarmasin. Panitia juga membuka sekretariat pendaftaran di sebuah warnet milik H. Risfani yang berada tepat sebelah kanan mesjid Jami' Teluk Dalam.

2. Peserta

Acara baayun mulud di mesjid Jâmi' Teluk Dalam, yang diselenggarakan pada hari Minggu tanggal 17 Rabî' al-Awwal 1432 H/20 Februari 2011 diikuti oleh 85 orang peserta. Dilihat dari segi usia peserta, mayoritas peserta merupakan anak-anak usia balita. Peserta tertua adalah seorang anak berusia sekitar 13 tahun duduk di kelas 1 SMP. Sedangkan dilihat dari asal daerah dan asal-usul kesukuan peserta, ternyata acara baayn mulud ini tidak saja diikuti oleh mereka yang berasal dari suku Banjar, tetapi juga diikuti oleh beberapa peserta yang berasal dari suku Jawa. Kesemua peserta merupakan warga Kota Banjarmasin yang bertempat tinggal di sekitar mesjid Jami'.

3. Perlengkapan/peralatan

Berbeda halnya dengan pelaksanaan baayun mulud di depan makam Sultan Suriansyah, kegiatan baayun mulud di Mesjid Jami' Teluk Dalam ini diadakan di dalam ruang utama mesjid sehingga panitia penyelenggara tidak lagi direpotkan dengan urusan mendirikan tenda. Panitia menyiapkan tiang-tiang ayunan yang terbuat dari kayu balok, tali ayunan, sarung batik dan 3 lembar kain berwarna kuning, hijau dan putih. Aksesoris ayunan berupa anyam-anyaman dari daun kelapa yang dipesan langsung dari kampung Baru Banjarmasin, sebuah kawasan 
yang terkenal sebagai sentra kerajinan anyaman ketupat. Panitian hanya menyiapkan satu perangkat piduduk (sesajian) untuk keseluruhan peserta.

Adapun berbagai perlengkapan/peralatan yang disediakan oleh panitia lebih rincinya adalah:

- Kain tiga lapis untuk peserta yang diayun;

- Tali, yang digunakan untuk menggantung kain ayunan;

- Tiang, yang berguna untuk mengikat tali dan berbagai hiasan-hiasan;

- Tapung Tawar yang terdiri dari air doa, mangkuk, daun pisang dan lain-lain;

- Piduduk, yang merupakan persyaratan acara baayun mulud, yang terdiri:

$\checkmark$ Piduduk kering yang meliputi: beras, gula merah, uang, benang, jarum, kelapa, telor, beras ketan.

$\checkmark$ Piduduk basah meliputi bermacam-macam kue seperti apam, cucur, cincin, kokoleh, ketupat, nasi ketan, tape, cingkaruk dan lain-lain. ${ }^{11}$

4. Pendanaan

Dana dihimpun melalui sumbangan dari peserta sebesar $\mathrm{Rp} 125.000$ perorang. Uang tersebut digunakan Rp 120.000 untuk pembelian perlengkapan ayunan, seperti: dua lembar kuning dan hijau, kain batik satu lembar dan tali serta pembelian piduduk dan Rp 5.000 untuk pembelian tiang ayunan (bambu). Di samping sumbangan dari setiap peserta, juga ada mendapat bantuan dari pemerintah daerah sebesar Rp 2.000.000,- Semua dana tidak dipungut untuk mesjid maupun untuk panitia.

5. Prosesi Upacara

Dalam suasana udara dingin kota Banjarmasin karena telah diguyur hujan pada malam harinya, di pagi hari minggu tanggal 17 Rabi'ul Awwal 1432 H/20 Februari 2011, diiringi dengan rintik-rintik gerimis sekitar pukul 07.00 pagi para peserta baayun mulud sudah mulai bersiap-siap di mesjid Jami' Teluk Dalam Banjarmasin Tengah. Kebanyakannya kaum ibu bersama anggota keluarganya yang akan diayun sudah mulai berkumpul di sekitar ayunan masing-masing. Panitia penyelenggara sudah menuliskan nama masing-masing peserta pada ayunan yang telah disiapkan. Tiang ayunan sengaja dibuat dari kayu kaso yang kokoh ukuran $5 \times 7 \mathrm{~cm}$ sehingga dapat digunakan untuk kegiatan serupa pada tahun-tahun berikutnya.

${ }^{11}$ Wawancara dengan Risfani pada tanggal 19 Juni 2011 
Ruang tengah mesjid digunakan untuk memancang tiang-tiang ayunan ini sehingga mampu menampung 85 orang peserta bersama masing-masing anggota keluarganya yang bertugas menggerakkan ayunan. Bagian dalam mesjid sebelah kiri digunakan sebagai tempat para petugas pembaca sya'ir maulid alHabsyi, sedangkan pada bagian dalam mesjid sebelah kanan atau berhadapan dengan para pembaca sya'ir maulid, digunakan sebagai tempat duduk para hadirin dari kaum laki-laki. Kaum ibu ditempatkan secara terpisah dari kaum laki-laki. Kaum ibu menempati bagian tengah mesjid di belakang tempat ayunan. Adapun bagian depan ditempati oleh penceramah, para ulama dan tokoh masyarakat.

Sekitar pukul 08.00 pagi, para petugas pembaca sya'ir maulid sudah mulai melantunkan sya'ir-sya'ir maulid al-Habsyi dan membacakan rawinya. Hadirin dan hadirat terlihat dengan khusyu menyimak lantunan sya'ir-sya'ir maulid yang dibawakan sambil sesekali menyahut/mengikuti bacaan sya'ir maulid yang dilantunkan. Seiring dengan pembacaan sya'ir-sya'ir maulid ini, para peserta baayun mulud yang pada umumnya adalah balita mulai diayun oleh ibu-ibunya.

Anehnya, meskipun hampir 1 setengah jam pembacaan sya'ir-sya'ir maulid yang diiringi dengan acara baayun ini berlangsung, tidak terdengar suara tangisan para peserta yang puluhan di antaranya merupakan bayi-bayi yang berumur kurang dari satu bulan. Bayi-bayi tersebut tampak senang-senang saja menikmati lantunan sya'ir-sya'ir maulid yang dibacakan. Bahkan, beberapa di antaranya sampai tertidur di dalam ayunan.

Sampai pada ketika pembacaan sya'ir Asyraqal, seluruh hadirin dan hadirat berdiri, tidak terkecuali kaum ibu yang bertugas mengayun anak-anak mereka. Selanjutnya, seorang ulama yang memakai serban dan baju gamis berdiri, kemudian berkeliling diikuti oleh beberapa orang tokoh masyarakat dengan dibantu seorang panitia yang bertugas mengangkat sebuah mangkok besar berisi air kembang berjalan mengitari seluruh peserta yang diayun. Ulama tersebut mengucapkan shalawat sambil memercikkan air kembang ke seluruh peserta yang berada dalam ayunan. Selesai memercikkan air kembang ke seluruh peserta baayun mulud, acara dilanjutkan dengan pembacaan do'a maulid sebagai penutup rangkaian pertama acara peringatan maulid Nabi Besar Muhammad saw.

Berikutnya, sekitar pukul 09.30 acara dilanjutkan dengan ceramah agama sekitar maulid Nabi Besar Muhammad saw. Sebelumnya, acara ini diawali dengan pembacaan ayat-ayat suci al-Qur’ân. Disusul dengan penyampaian sambutan berupa laporan dari panitia penyelenggara peringatan maulid Nabi 
Besar Muhammad saw. mesjid Jami' Teluk Dalam. Kemudian memasuki acara puncak, berupa ceramah agama sekitar maulid Nabi Besar Muhammad saw. yang disampaikan oleh K.H. Husin Nafarin, Lc., M.A.

K.H. Husin Nafarin, Lc., M.A. dalam ceramahnya memaparkan tentang bagaimana menjadikan Rasulullah saw. sebagai figur idola dengan meneladani akhlak-akhlaknya yang mulia dan agar sejak dini para orang tua memberikan keteladanan yang baik bagi anak-anak mereka. Sampai sekitar pukul 11.00 siang, ceramah pun berakhir, ditutup dengan do'a dari sang penceramah.

6. Kendala dan Tantangan yang Dihadapi

Menurut pengakuan H. Risfani sebagai pemakarsa dan koordinator kegiatan ini, bahwa panitia pelaksana baayun mulud tahun ini dipandang kurang begitu siap, sebab tidak sempat membuat ayunan besar dalam bentuk rumah Banjar yang dipasang di depan mesjid, yang disebabkan keadaan cuaca yang kurang mendukung yaitu terjadi hujan lebat dalam waktu yang cukup lama. Setiap upacara baayun mulud lazimnya ayunan besar ini selalu ada. Di sini tempat berayun para pejabat dan ada potografer khusus untuk mengabadikan siapa yang berkeinginan berfoto di tempat itu.

Koordinator panitia pelaksana, Bpk H. Risfani lebih jauh mengungkapkan bahwa, panitia kegiatan baayun mulud di Mesjid Teluk Dalam untuk tahun 2011 ini tampak kurang mantap melakukan persiapan, hal ini karena panitia tidak menduga besarnya antusias warga untuk mengikuti kegiatan ini. Di samping itu, karena kegiatan ini sempat terhenti beberapa tahun setelah terakhir diadakan pada tahun 2005. Terhentinya kegiatan ini selama beberapa tahun, menurutnya karena yang menjadi pengurus Mesjid Teluk Dalam pada periode tersebut kurang mendukung diadakannya acara ini.

\section{Tujuan dan Motivasi Peserta Baayun Mulud}

Sebagian besar peserta mengaku mengikutsertakan anaknya dalam kegiatan baayun mulud ini karena berharap mendapatkan keberkahan dari Allah swt terhadap anak-anak mereka; agar anak-anak mereka menjadi anak yang shaleh dan shalehah. Ada juga beberapa di antaranya yang mengikutsertakan anaknya karena sebelumnya pernah bernadzar akan mengadakan acara baayun mulud jika anaknya sembuh dari sakitnya. ${ }^{12}$

Dari hasil wawancara langsung dengan keluarga yang mengikutsertakan anaknya atau anggota keluarganya dalam acara baayun mulud, terungkap berbagai

${ }^{12}$ Wawancara dengan Bapak Risfani pada tanggal 12 Juni 2011 
tujuan dan kepercayaan yang menjadi dasar keikutsertaannya dalam acara baayun mulud tersebut, antara lain: karena nazar, melestarikan tradisi, ikut merayakan hari kelahiran Nabi, menciptakan rasa kekeluargaan, dan karena perasaan kuatir bila tidak melaksanakan akan sakit, karena sudah dilakukan secara turun temurun. ${ }^{13}$

Seorang responden menuturkan keikutsertaannya dalam baayun mulud karena nazar. Setelah sakit yang cukup lama diderita, sehingga ketika sembuh ia bernazar untuk selalu ikut serta dalam upacara baayun. ${ }^{14}$ Lain lagi dengan Ibu $\mathrm{Hj}$. Norlatifah, seorang peserta tertua berusia tidak kurang dari 60 tahun, berasal dari Belitung Darat Banjarmasin. Mengaku telah mengikuti acara baayun mulud untuk kedua kalinya di tempat yang sama. Alasan ikut acara ini adalah karena setahun sebelumnya, ia telah bernazar bahwa kalau ia dalam keadaan sehat wal 'afiat selama satu tahun terakhir, maka ia akan ikut kegiatan ini pada tahun ini. ${ }^{15}$

Detalia A. menuturkan tentang keluarganya yang bernama Aditia selalu ikut baayun mulud dengan kemauannya sendiri, tanpa ada yang mengajak. Kemauannya untuk ikut baayun mulud apabila tidak disetujui oleh orang tuanya dia akan marah, cengeng dan nakal. Memang diakui oleh keluarganya Aditia mempunyai hubungan persahabatan dengan mahluk gaib (bagampiran). Dan orang tuanya selalu menyediakan kopi pahit dan manis setiap malam Jumat. Lain halnya dengan Filyan yang ikut baayun mulud hanya untuk ikut memeriahkan, selain perwujudan rasa syukur karena telah diberikan limpangan rejeki. ${ }^{16}$

Hj. Mahmudah Herliani, yang mengaku mengikutsertakan anak lakilakinya yang berumur dua tahun M.Atha Mudzhar dalam acara baayun mulud ini dengan harapan agar anaknya kelak menjadi anak yang saleh, cinta kepada Rasulullah saw dan mendapat limpahan keberkatan dari Allah swt. ${ }^{17}$

Motivasi lainnya, terungkap dari hasil wawancara dengan penjaga Makam Sultan Suriansyah, Bapak H. Burhan yang menyatakan bahwa tradisi ini baik dikembangkan di tengah masyarakat muslim sekarang ini, gunanya untuk lebih mempererat kebersamaan, hubungan persaudaran, dan persatuan masyarakat, juga untuk memberikan alternatif bagi masyarkat muslim dalam memperingati

\footnotetext{
${ }^{13}$ Wawancara dengan Amang Tiak pada 12 Juni 2011

${ }^{14}$ Wawancara dengan Aluh pada Tanggal 12 Juni 2011

${ }^{15}$ Wawancara dengan Hj. Lathifah pada Tanggal 15 Pebruari 2011

${ }^{16}$ Wawancara dengan Detali A pada 19 Juni 2011

${ }^{17}$ Wawancara dengan Hj. Mahmudah H pada tanggal 20 Juni 2011
} 
hari kelahiran (ulang tahun) anak-anak mereka. Katanya, "Gasan kakanakan," ("Bagi anak-anak") "Dari pada diperdengarkan nyanyian-nyanyian, lebih baik jika diperdengarkan bacaan sya'ir-sya'ir maulid."

Hampir seluruh peralatan ritual yang disediakan atau digunakan untuk acara Baayun Mulud, dipercayai mengandung beragam makna filosofis. Makna simbolik dari benda-benda yang disediakan tersebut ada yang bersifat umum dan ada pula yang bersifat khusus sesuai dengan harapan yang dicita-citakan peserta yang menyediakannya.

Di antara makna filosofis yang bersifat umum dari benda-benda yang digunakan adalah:

- Ayunan (buaian) yang terdiri dari kain sarung panjang wanita atau berupa selendang melambangkan peralatan kedaerahan atau budaya lokal yang dipertahankan kelestariannya. Hal ini juga melambangkan kesucian. Seorang wanita harus menjaga kesuciannya termasuk untuk selalu menutup aurat;

- Kain kuning sebagai simbol keramat, dengan kain kuning tersebut diharapkan agar anak yang diayun ini nantinya memperoleh kemuliaan (keramat);

- Beras kuning melambangkan agar wajah menjadi bagus, indah dan bercahaya;

- Nasi ketan, melambangkan kecintaan kepada nabi selalu melekat;

- Telor menggambarkan kebulatan persaudaraan yang kokoh;

- Tapung tawar untuk menapungtawari peserta.

- Piduduk (sesajian yang terdiri dari: beras, kelapa, gula merah, garam, dll):

$\checkmark$ Beras merupakan kebutuhan pokok, sebagai simbol kesejahteraan, yakni berkecukupan dalam soal makanan pokok;

$\checkmark$ Kelapa merupakan buah yang serbaguna, sebagai simbol kemanfaatan;

$\checkmark$ Gula merah sebagai melambangkan tutur bahasa manis atau menarik;

$\checkmark$ Garam sebagai simbol pengaruh/kewibawaan dengan harapan semoga sang anak menjadi orang yang berpengaruh/berwibawa sehingga katakatanya diperhatikan orang;

$\checkmark$ Benang menggambarkan tentang urat nadi, diharapkan nantinya selama hidup akan mempunyai ikatan yang kuat dengan keluarga;

18 Wawancara pada hari Jum'at, 22 April 2011 di makam Sultan Suriansyah Kelurahan Kuin Utara Kecamatan Banjarmasin Utara Kota Banjarmasin Provinsi Kalimantan Selatan. 
$\checkmark$ Jarum melambangkan tulang dalam tubuh. Ini mempunyai harapan yang ikut baayun mulud menjadi orang yang bermanfaat besar bagi orang lain;

$\checkmark$ Uang logam melambangkan bahwa dalam kehidupan ini memerlukan biaya. Karena uang itu memegang peran penting dalam kehidupan ini. Uang logam ini berisi harapan agar mudah rezeki, lancar usaha dan tidak kekurangan;

- Anyaman-anyaman berupa:

$\checkmark$ Ular-ular melambangkan kehidupan yang penuh dengan liku-liku;

$\checkmark$ Sapit bundang melambangkan adanya kesukaran/kesulitan yang dapat diterima dengan suatu kekuatan;

$\checkmark$ Rantai gagalangan, merupakan gambaran betapa kuatnya persaudaraan, rantai ini berjumlah 25 buah, sebagai kiasan banyaknya jumlah nabi dan rasul itu 25 orang. ${ }^{19}$

\section{Tradisi Baayun Mulud dalam Perspektif}

Islam yang ideal adalah Islam sebagaimana dicontohkan atau yang diajarkan oleh Nabi Muhammad saw. Sedangkan Islam seperti yang senyatanya terjadi dalam masyarakat disebut Islam historis, Islam kontekstual atau disebut juga Islam empiris, yakni Islam dalam kenyataan yang dapat diamati, benarbenar terjadi, benar-benar diamalkan oleh manusia atau masyarakat, terkait atau yang disesuaikan dengan konteks ruang dan waktu, kapan dan di mana Islam diamalkan oleh manusia atau masyarakat tersebut. ${ }^{20}$

Islam yang ada di Kalimantan Selatan sebagaimana yang dipraktekkan oleh masyarakat suku Banjar merupakan Islam yang telah dipengaruhi oleh historisitas wilayah ini. Sekalipun masyakarat Banjar dapat dinilai sudah cukup maju dari aspek pendidikan, ekonomi, dan pengetahuan keberagamaan, namun budaya atau adat-istiadat yang sudah melekat dalam kehidupan masyarakat Banjar jauh sebelum kedatangan Islam di daerah ini tetap saja terasa kental mewarnai corak keberagamaan mereka saat ini. Hal ini sangat dirasakan dalam pelaksanaan tradisi baayun mulud ini.

Bagi orang Islam, secara umum peringatan maulid nabi biasanya dimaksudkan untuk mengenang kembali peristiwa bersejarah lahirnya Nabi Muhammad saw, seorang tokoh besar pembawa risalah ilahi yang segala sisi dari hidup dan kehidupannya mengandung 'ibrah dan merupakan teladan dalam

${ }^{19}$ Wawancara dengan Bardi, M. Akli dan Munia pada Tanggal 20 Juni 2011

${ }^{20}$ Khadziq, Islam dan Budaya Lokal (Yogyakarta: Teras, 2009), Cet.ke-1, h. 10-11. 
mencapai kebahagiaan hidup di dunia dan di akhirat. Bagi seorang muslim, memperingati maulid Nabi Muhammad saw merupakan sebuah ekspresi keberagamaan, mulai dari rasa syukur atas kehadiran seseorang yang sangat berjasa; pembawa cahaya petunjuk dari "alam kegelapan ke alam yang terangbenderang." Hingga rasa cinta kepada sosok sang pembawa risalah yang memiliki akhlak dan budi pekerti mulia.

Sekalipun tidak ditemukan contoh tentang peringatan maulid dari Sang Nabi sendiri, demikian pula dari para sahabatnya, sebagian besar umat Islam yang menyelenggarakan peringatan maulid Nabi Muhammad saw meyakini atau mempercayai bahwa apa yang mereka lakukan bukanlah sesuatu yang terlarang dalam Islam, namun justeru sebaliknya, merupakan sesuatu yang bernilai ibadah kepada Allah swt, karena bagi mereka tujuan peringatan tersebut adalah diniatkan agar umat Islam mengenal lebih dekat sosok dan kepribadian sang Nabi sehingga dapat lebih mencintainya dan kemudian meneladani jejak langkahnya dalam hidup dan kehidupan.

Dimensi religiusitas dalam upacara baayun mulud, jelas sekali tampak bagi siapa pun yang hadir menyaksikannya. Bagi mereka yang memandang dari sisi historisitas Islam dan yang meyakini karakter kosmopolitan Islam sebagai agama, mungkin akan menilai bahwa nafas Islam telah berhasil menjadi ruh bagi sebuah tradisi budaya lokal yang telah lama dikenal oleh masyarakat Banjar. Akan tetapi, bagi mereka yang lebih menekankan sisi normativitas Islam sebagai ajaran Ilahi, mungkin akan menilai bahwa tradisi tersebut merupakan sebuah sinkritisme yang seharusnya dimurnikan dari ajaran Islam.

Tidak ada yang mengingkari bahwa Islam bukanlah agama atau kepercayaan pertama yang dikenal oleh penduduk asli yang menghuni wilayah nusantara. Islam sebagaimana juga Hindu, Budha, dan Kristen merupakan agama-agama atau kepercayaan baru bagi penduduk asli di wilayah nusantara. Agama atau kepercayaan asli Indonesia, menurut ahli agama-agama primitif, Prof. Rachmat Subagya, merupakan konsep-konsep keruhanian dalam masyarakat suku yang secara internal tumbuh, berkembang dan mencapai kesempurnaannya sendiri tanpa imitasi atau pengaruh eksternal. ${ }^{21}$

Secara kronologis dapat disebutkan bahwa agama Hindu dan Budha merupakan dua agama yang pertama kali berinteraksi dengan kepercayaan asli Indonesia. Sementara agama Islam merupakan agama ketiga yang mencapai

\footnotetext{
${ }^{21}$ Rachmat Subagya, Kepercayaan Kebatinan, Kerohanian, dan Agama, (Jakarta: Yayasan Kanisius, 1970), h. 31.
} 
batas-batas wilayah nusantara setelah sebelumnya wilayah ini dirasuki secara mendalam oleh agama Hindu dan Budha. Agama Hindu dan Budha mengalami perkembangan pesat di wilayah nusantara sejak abad pertama dan kedua Hijriah. Di Sumatera dan Jawa berdiri kerajaan-kerajaan yang memiliki keterkaitan dengan kedua agama tersebut. Peninggalan besar kedua agama tersebut berupa candi Prambanan dan candi Borobudur merupakan saksi sejarah yang paling otentik suksesnya perkembangan kedua agama tersebut di wilayah nusantara.

Adapun di wilayah Kalimantan Selatan, berdasarkan hikayat yang dihimpun J.J. Ras, seperti dikutip Mujiburrahman, dinyatakan bahwa kerajaan pertama yang muncul di daerah ini adalah kerajaan Tanjungpura yang berpusat di Tanjung dan didirikan oleh para imigran Melayu Sriwijaya yang beragama Budha. Kemudian pada abad XIII, kaum imigran dari Jawa mendirikan kerajaan Negara Dipa di Amuntai dan menganut agama Hindu. Oleh karenanya dapat disimpulkan bahwa sebelum Islam menjadi agama resmi kerajaan Banjar, masyarakat di wilayah ini, sebagaimana halnya masyarakat di wilayah lainnya di nusantara, telah mengenal Budhisme dan Hinduisme selain kepercayaankepercayaan primitif seperti animisme, dinamisme dan shamanisme. ${ }^{22}$

Perkembangan Islam di tengah masyarakat Banjar tidak terlepas dari perkembangan Islam di wilayah nusantara secara umum. Islamisasi di wilayah nusantara lebih kurang terjadi antara abad XIII hingga abad XV masehi. Proses Islamisasi ini terjadi secara perlahan, berangsur-angsur hingga Islam berintegrasi dengan berbagai budaya yang ada di nusantara. ${ }^{23}$ Proses penyebaran dan pemelukan agama Islam di kepulauan nusantara yang berlangsung secara massif dan dengan jalan damai tersebut sempat dicatat oleh Marshall Hodgson sebagai prestasi sejarah dan budaya yang amat sangat mengagumkan. ${ }^{24}$ Di sisi lain, konversi ke dalam agama Islam yang berlangsung secara damai tersebut tentunya dibarengi dengan tingkat akomodasi yang tinggi dari agama Islam sebagai pendatang baru terhadap institusi-institusi agama dan kepercayaan yang sudah ada.

${ }^{22}$ Mujiburrahman, Mengindonesiakan Islam: Representasi dan Ideologi, (Yogyakarta: Pustaka Pelajar, 2008), h. 389.

${ }^{23}$ Mujiburrahman, Mengindonesiakan Islam..., h. 387.

${ }^{24}$ Baca dalam M. Amin Abdullah, Studi Agama: Normativitas atau Historisitas?, (Yogyakarta: Pustaka Pelajar, 1996), h. 5 \& 19. Menurut Amin Abdullah, Hodgson sengaja menonjolkan aspek ini sebagai jawaban atas tesis Cliiford Geertz yang kurang apresiatif terhadap hasil budaya yang sangat mengagumkan tersebut. 
Pengaruh agama-agama sebelumnya atau kepercayaan asli Indonesia terhadap agama-agama pendatang, tidak terkecuali agama Islam merupakan realitas yang tidak dapat dimungkiri. ${ }^{25}$ Bahkan menurut Seno Harbangan Siagian, setiap orang Indonesia bagaimanapun majunya, tetap terpengaruh oleh agama asli yang sedikit banyaknya melekat pada keyakinan barunya, baik dia seorang pengikut Hindu, Budha, Islam, maupun Kristen. ${ }^{26}$

Realitas keberagamaan tersebut di atas juga terjadi di tengah-tengah masyarakat muslim yang tinggal di kota Banjarmasin hingga saat ini. Kasus berupa upacaya baayun mulud merupakan salah satu bentuk realitas keberagamaan dimaksud. Upacara yang merepresentasikan sebuah tradisi budaya khas masyarakat Banjar ini tidak saja diliputi oleh unsur-unsur Islam, tetapi juga diwarnai oleh tradisi agama atau kepercayaan selain Islam.

Unsur-unsur Islam yang tampak jelas dari upacara tersebut, di antaranya adalah: Pertama, bahwa upacara tersebut digelar seiring dengan peringatan kelahiran pembawa risalah Islam, yaitu Nabi Muhammad saw. Kedua, upacara baayun mulud ini diikuti seluruhnya oleh orang yang mengaku muslim, baik peserta yang diayun, keluarga dan kerabatnya yang hadir maupun panitia yang mengadakan acara. Ketiga, bacaan-bacaan baik berupa ayat-ayat al-Qur ân, do'a-do'a yang dipanjatkan, maupun sya'ir-sya'ir yang dilantunkan keseluruhannya merupakan representasi dari unsur-unsur Islam. Keempat, tempat penyelenggaraan acara baayun mulud ini, baik di mesjid maupun di komplek pemakaman sultan (gelar untuk penguasa di Kerajaan Banjar yang beragama Islam), keduanya merupakan simbol-simbol Islam. Kelima, salah satu rangkaian acara dalam kegiatan baayun mulud ini adalah ceramah agama yang diisi oleh seorang ulama yang tentunya merupakan representasi dari pemuka agama Islam.

Adapun unsur-unsur asing dari luar Islam yang segera tampak dari acara baayun mulud ini adalah pertama, dari peralatan yang disiapkan dan dipergunakan, yaitu seperti Adanya semacam sesajian yang oleh masyarakat Banjar disebut dengan istilah piduduk dan anyaman-anyaman beragam bentuk

\footnotetext{
${ }^{25}$ Alwi Shihab, Antara Tasawnf Sunni dan Tasawnf Falsafi: Akar Tasawnf di Indonesia, (Jakarta: Pustaka Iiman, 2009), h. 1.

${ }^{26}$ Seno Harbangan Siagian, Agama-Agama di Indonesia, (Semarang: Setia Wacana, 1987), h. 1-5; Baca juga Mark R. Woodward, Islam Jawa Kesaleban Normatif Versus Kebatinan, terj. Oleh Hairus Salim dari judul asli Islam in Java: Normative Piety and Misticism, (Yogyakarta: Lkis, 2008); Slamet Muljana, Runtubnya Kerajaan Hindu-Jawa dan Timbulnya Negara-negara Islam di Nusantara, (Yogyakarta: Lkis, 2009).
} 
terbuat dari daun nipah atau daun kelapa sebagai pernak-pernik penghias ayunan. Kedua, pada saat prosesi acara baayun mulud berlangsung, seorang ulama yang memimpin do'a berkeliling ke seluruh peserta yang diayun sambil memercikkan air kembang yang telah dido'akan (sehingga dipercaya mengandung berkah) ke arah peserta. Prosesi seperti ini oleh masyarakat Banjar disebut dengan istilah batutungkal.

Jika ditinjau secara normatif, upacara baayun mulud yang dalam pelaksanaannya melibatkan unsur-unsur Islam dan non-Islam tersebut akan memunculkan pertanyaan seperti: Apakah pengaruh-pengaruh kepercayaan atau agama-agama sebelumnya dalam upacara tersebut merupakan sesuatu yang masih dapat ditoleransi oleh Islam ataukah sebuah sinkritisme yang seharusnya dihapuskan atas nama kemurnian agama Islam?

Sebelum dikemukakan analisis pandangan Islam secara normatif terhadap kasus tersebut, perlu ditegaskan sebelumnya bahwa pelaksanaan acara peringatan maulid Nabi Muhammad saw sendiri tidaklah disepakati kebolehannya oleh seluruh ulama dari kalangan umat Islam.

Kelompok yang belakangan mengklaim dirinya sebagai kaum salafi misalnya, dengan tegas menolak acara-acara semacam itu. Menurut mereka, acara seperti itu termasuk kategori bid'ah, karena jangankan diperintahkan, dikerjakan pun tidak pernah oleh Rasulullah saw. Demikian pula oleh para sahabatnya, hingga tiga generasi pertama umat Islam, mereka tidak pernah melakukannya. ${ }^{27}$ Senada dengan pandangan kelompok ini, kelompok-kelompok Islam di Indonesia yang biasanya dikategorikan sebagai kelompok modernis, seperti Persis dan Muhammadiyah juga mengecam pelaksanaan acara peringatan maulid nabi karena menganggapnya sebagai $b i d^{\prime} a b^{28}$

Jika forum yang mengagendakan acara peringatan maulid Nabi Muhammad saw saja dikecam sebagai bid'ah yang terlarang oleh kelompokkelompok tersebut di atas, maka apatah lagi acara tradisi budaya baayun mulud

${ }^{27}$ Baca fatwa Shâlih bin Fauzân bin 'Abdillah al-Fauzân, Kitâb al-Tauhîid, (al-Mamlakah al-'Arabiyyah al-Sa'udiyyah: Wizârah al-Syu'ûn al-Islâmiyyah wa al-Awqâf wa al-Da'wah wa alIrsyâd, 1423 H), juz I, h. 155; 'Abd al-'Azîz bin 'Abdullah bin Bâz, Fatâwâ al-Mar'ah alMuslimah, (Kairo: Dâr Ibn al-Jauzî, 2005), h. 556; Baca juga kitab al-Mausu'ah al-Radd 'alâ alShûfíyyah dan kitab al-Jâmi' fi al-Maulid yang merupakan Majmû'ah Maqâlât wa Fatâwâ 'an al-Inhtifâl bi al-Maulid al-Nabawr̂, dalam al-Maktabah al-Syâmilah, al-Ishdâr 3,5 atau diunduh di http://www.shamela.ws

${ }^{28}$ Baca dalam Ali Romdhoni (ed.), Nalar Islam Nusantara: Studi Islam ala Mubammadiyah, al-Irsyad, Persis, dan NU, (Jakarta: Direktorat Pendidikan Tinggi Islam Depag RI, 2007), h. $107-112 \& 243-244$. 
yang seperti telah diungkapkan banyak mengandung unsur-unsur sinkritisme antara Islam dan non-Islam.

Memang diakui bahwa dalam pelaksanaan tradisi baayun mulud di kota Banjarmasin masih terdapat beberapa fenomena yang dapat dianggap sebagai sisa-sisa ritus pra-Islam. Akan tetapi, sudah tidak terdeteksi lagi kepercayaan atau aqidah yang benar-benar dapat dinilai menyimpang dari ajaran Islam. Contoh konkritnya adalah sesajian atau yang disebut dengan piduduk yang disediakan di sekitar ayunan oleh keluarga yang diayun. Jika dahulunya sesajian atau piduduk tersebut dimaksudkan sebagai persembahan bagi makhluk gaib atau roh-roh halus yang dapat mengganggu. Sekarang ini, keberadaan piduduk. tersebut hanyalah dianggap sebagai pernak-pernik budaya yang melengkapi gelaran sebuah tradisi. Asumsi pertama bahwa piduduk tersebut disediakan karena adanya kepercayaan terhadap pengaruh roh-roh halus atau makhlukmakhluk gaib tampaknya tidak dapat dipertahankan karena ternyata sesajen berupa makanan, telor, dan kue-kue yang dihamparkan tersebut, akhirnya justru jadi bahan rebutan anggota keluarga peserta untuk dinikmati bersamasama sehingga tidak ada lagi sisa sesajen yang awalnya diduga akan diberikan kepada makhluk gaib.

Kepercayaan terhadap adanya makhluk gaib atau roh-roh halus yang dapat berpengaruh terhadap kehidupan manusia sebenarnya telah lama dikenal oleh masyarakat di daerah ini. Sejak abad ke-18 M, kepercayaan tersebut telah dikecam keras oleh Syekh Muhammad Arsyad al-Banjari (1712-1810), dalam kitabnya, Tuhfat al-Râghibîn fî Bayân Haqîqat al-Müminîn wa Mâ Yufsidu min Riddat al-Murtaddinn. ${ }^{29}$ Untuk kasus pemberian sesajen, Syekh Arsyad al-Banjari menulis:

Syahdan, babwa telah terdabulu perkataan babwasanya sanggar dan buang pesilih itu bid'ah haram yang amat keji karena mengandung ia akan beberapa pekerjaan yang ijma' sekalian ulama atas haramnya. Maka barang siapa menghalalkan pekerjaan itu, maka jadilah ia kafir murtad dengan tiada kbilaf sama ada dikerjakan pekerjaan itu atau tiada. Dan barangsiapa mengerjakan dia pekerjaan itu dengan tiada dibalalkan akan dia, tetapi di'itikadkannya babwa yang disanggar dan yang diberi pesilib itu memberi bekas ia dengan perangainya pada penyakitnya dan mewarasi, dan menolakkan bahaya maka orang itu jadi kafir dengan ittifak sekalian ulama. Dan barangsiapa mengi'tikadkan yang demikian itu

${ }^{29}$ Muhammad Arsyad bin 'Abdullah al-Banjari, Tuḩfat al-Râghibîn fî̀ Bayân Haqaîaat alMu minîn wa Mâ Yufsidu min Riddat al-Murtaddîn,(Banjarmasin: Toko Buku Murni, 1983). 
memberi bekas dengan kuat yang dijadikan Allah Ta'ala dalamnya, maka orang itu jadi kafir, tetapi dengan ikhtilaf mereka itu, dan jadi bid'ah fasik ia dengan tiada kbilaf mereka itu. Dan barangsiapa mengerjakan itu dengan tiada dibalalkannya akan dia dan tiada dii'tikadkannya akan dia memberi bekas pada suatu juapun, maka orang itu jadi bid'ah fasik. dengan perbuatanny a yang demikian itu, maka atas tiap-tiap hal wajiblah orang yang menghalalkan dan mengerjakan pekerjaan itu segera taubat dan minta ampun kepada Allah Ta'ala dengan segala syaratnya dan janganlah ia putus asa daripada rahmat Allah. ${ }^{30}$

Kecaman keras tokoh ulama besar yang sangat disegani di Kalimantan Selatan tersebut tampaknya cukup efektif dan berhasil dalam meluruskan kepercayaan masyarakat muslim Banjar, khususnya ketika mereka menggelar tradisi-tradisi budaya yang di dalamnya melibatkan semacam sesajian-sesajian. Efektivitas dan keberhasilan kritik Syekh Arsyad al-Banjari dalam hal ini terbukti dari tidak adanya lagi ditemukan masyarakat yang mengakui bahwa sesajian yang mereka siapkan dalam upacaya baayun mulud dipersembahkan kepada roh-roh gaib atau makhluk halus yang dapat berpengaruh terhadap kehidupan mereka. Perangkat piduduk (sesajian) yang mereka siapkan, demikian pula beragam aksesoris yang menghiasi ayunan, pada kenyataannya lebih dipandang dari sisi makna simbolik yang terkandung di dalamnya.

\section{Penutup}

Sebagian masyarakat Banjar dalam melaksanakan perayaan atau peringatan hari kelahiran Nabi Muhammad saw diisi dengan acara mengayun anak atau orang dewasa, yang lazim disebut dengan istilah baayun mulud.

Upacara baayun mulud di depan makam Pangeran Suriansyah pada tanggal 12 Rabiul Awal 1432 H., atau 15 Pebruari 2011 M., telah diikuti 117 orang peserta yang umumnya anak-anak, hanya tiga orang yang dewasa. Sedangkan di mesjid Jami' Teluk Dalam dilaksanakan pada tanggal 17 Rabiul Awal 1432 H. atau 20 Pebruari 2011 M., dengan jumlah peserta sebanyak 85 orang anak-anak. Mereka yang ikut tidak hanya dari Banjarmasin tetapi juga ada yang dari daerah Kapuas dan Batulicin. Pada upacara baayun mulud ini disediakan berbagai perlengkapan berupa ayunan, piduduk (sesajian), kue-kue, buah-buahan dan hiasan-hiasan dengan makna tersendiri. Acara ini digelar pada

\footnotetext{
${ }^{30} \mathrm{Abu}$ Daudi, Transliterasi Kitab Tubfaturraghibin, (Martapura: Yapida, 2000), h. 46. "Sanggar" atau "menyanggar" artinya: memberikan sesajen kepada leluhur. Sedangkan "membuang pesilih" artinya: membuang pakaian yang pernah dipakai dengan tujuan membuang sial.
} 
pagi hari, yang diisi dengan pembacaan syair maulid nabi. Untuk daerah Kuin Utara tepatnya di makam Pangeran Suriansyah membaca syair syaraful anam, dan pada mesjid Jami' Teluk Dalam membaca syair al-Habsyi. Acara dilanjutkan dengan pembacaan kalam Ilahi, sambutan panitia pelaksana, dan ceramah agama. Penceramah di makam Pangeran Suriansyah adalah ustaz H. Ali Furqan dan pada mesjid Jami' penceramahnya adalah KH. Husin Nafarin, Lc. M.A.

Ada berbagai motivasi dan tujuan dari peserta dalam mengikuti acara baayun mulud ini, di antaranya adalah adanya kepercayaan akan terkabulnya segala hajat; mendapatkan berkah, kesehatan, keselamatan, sembuh dari sakit, anak tidak nakal/rewel dan karena menunaikan nazar yang sebelumnya telah dikabulkan Allah swt.

\section{Daftar Pustaka}

Abdullah, M. Amin, Studi Agama: Normativitas atau Historisitas?, (Yogyakarta: Pustaka Pelajar, 1996.

Abu Daudi, Transliterasi Kitab Tuhfaturragbibin, Martapura: Yapida, 2000.

al-'Amanily, Ja'far Murtadha, Perayaan Maulid, Khaul dan Hari-hari Besar Islam Bukan Sesuatu yang Haram, diterjemahkan dari judul aslinya al-Mawasin wa al-Marasim oleh Masykur Ab, Bandung: Pustaka Hidayah, 1996.

Badan Pusat Statistik Kota Banjarmasin, Kecamatan Banjarmasin Tengah dalam Angka: Banjarmasin Tengah In Figures 2010.

al-Banjari, Muhammad Arsyad bin 'Abdullah, Tubfat al-Râghibîn fî Bayân $\underline{\text { Haqî̀qat }}$ al-Müminîn wa Mâ Yufsidu min Riddat al-Murtaddîn, Banjarmasin: Toko Buku Murni, 1983.

Basuni, Ahmad, Nur Islam di Kalimantan Selatan, (Sejarah Masuknya Islam di Kalimantan, Surabaya: PT. Bina Ilmu,1986.

bin Bâz, 'Abd al-'Azîz bin 'Abdullah, Fatâwâ al-Mar'ah al-Muslimah, Kairo: Dâr Ibn al-Jauzî̀, 2005.

bin Fauzân, Shâlihh, bin 'Abdillah al-Fauzân, Kitâb al-Taubî̀d, al-Mamlakah al'Arabiyyah al-Sa'udiyyah: Wizârah al-Syu'ûn al-Islâmiyyah wa al-Awqâf wa al-Da'wah wa al-Irsyâd, 1423 H, juz I.

Bustanuddin, Agus, Agama dalam Kehidupan Manusia, Jakarta: PT.RajaGrafindo Persada, 2006. 
Daud, Alpani, Islam dan Budaya Banjar, Jakarta, PT RajaGrafindo Persada, 1997.

Hasyim, Umar, Syetan Sebagai Tertuduh dalam Masalah Sibir Tahayul Pedukunan dan Azimat, Surabaya, PT. Bina Ilmu, 1989.

Ibn Qayyim al-Jauziy, Imam Syamsuddin Abi Abdillah, Masalab Ruh, diterjemahkan oleh Jamaluddin Kafie dari judul aslinya al-Rub Li Ibnil Qayyim, Surabaya: PT. Bina Ilmu, 1979.

Ideham, M. Suriansyah, et.al, Urang Banjar dan Kebudayaannya, Banjarmasin: Badan Penelitian dan Pengembangan Daerah Provinsi Kalimantan Selatan, 2005.

Khadziq, Islam dan Budaya Lokal, Yogyakarta: Teras, 2009.Mochrani, Agama dan Kemasyarakatan, Banjarmasin: PPPTAI/IAIN, 1982.

Mujiburrahman, Mengindonesiakan Islam: Representasi dan Ideologi, Yogyakarta: Pustaka Pelajar, 2008.

Muljana, Slamet, Runtubnya Kerajaan Hindu-Jawa dan Timbulnya Negara-negara Islam di Nusantara, Yogyakarta: Lkis, 2009.

Nordiansyah, Sinkretisme, Banjarmasin: Fakultas Ushuluddin IAIN Antasari, 1982.

Romdhoni, Ali (ed.), Nalar Islam Nusantara: Studi Islam ala Mubammadiyah, alIrsyad, Persis, dan NU, Jakarta: Direktorat Pendidikan Tinggi Islam Depag RI, 2007.

Sani, Mukhyar, Dakwah Islam dan Perkembangannya di Kalimantan Selatan, Banjarmasin, Al-Hadharah, 2003.

Shihab, Alwi, Antara Tasamuf Sunni dan Tasawnf Falsafi: Akar Tasamuf di Indonesia, Jakarta: Pustaka Iiman, 2009.

Siagian, Seno Harbangan, Agama-Agama di Indonesia, Semarang: Setia Wacana, 1987.

Sjarifuddin, et.al, Sejarah Banjar, Banjarmasin: Badan Penelitian dan Pengembangan Daerah Provinsi Kalimantan Selatan, 2004.

Subagya, Rachmat, Kepercayaan Kebatinan, Kerobanian, dan Agama, Jakarta: Yayasan Kanisius, 1970. 
Tambusai, Musdar Bustaman, Buku Pintar Jin, Sibir dan Ruqyah Syar'iyyah, Jakarta Timur : Pustaka al-Kautsar, 2010.

Wajidi, Akulturasi Budaya Banjar di Banua Halat, Yogyakarta: Pustaka Book Publisher, 2011.

Woodward, Mark R., Islam Jawa Kesaleban Normatif Versus Kebatinan, terj. Oleh Hairus Salim dari judul asli Islam in Java: Normative Piety and Misticism, Yogyakarta: Lkis, 2008. 